Research Paper

\title{
Efficacy of surgery and prophylactic cranial irradiation in stage II and III small cell lung cancer
}

\author{
Kunpeng Yin ${ }^{1 *}$, Dandan Song ${ }^{*}$, Hongwei Zhang ${ }^{1}$, Feng Cai ${ }^{1}$, Jun Chen ${ }^{2}$, Jun Dang ${ }^{1 凶}$ \\ 1. Department of Radiation Oncology, The First Hospital of China Medical University, Shenyang, China \\ 2. Department of Radiation Oncology, Shenyang Chest Hospital, Shenyang, China \\ * Kunpeng Yin and Dandan Song contributed equally to this work. \\ $\triangle$ Corresponding author: Jun Dang. Department of Radiation Oncology, The First Hospital of China Medical University. 155 Nanjing Road, Heping District, \\ Shenyang, 110001, China. Tel: +86-24-83282137. Email: dangjunsy@163.com \\ (c) Ivyspring International Publisher. This is an open access article distributed under the terms of the Creative Commons Attribution (CC BY-NC) license \\ (https://creativecommons.org/licenses/by-nc/4.0/). See http://ivyspring.com/terms for full terms and conditions.
}

Received: 2018.03.19; Accepted: 2018.07.25; Published: 2018.09.08

\begin{abstract}
Background: The role of surgery for stage II and III small cell lung cancer (SCLC) remains controversial. The use of prophylactic cranial irradiation (PCI) for resected SCLC was limited. This study aimed to assess the efficacy of surgery in patients with stage II and III SCLC, and evaluate the value of $\mathrm{PCl}$ on resected disease.

Methods: A total of 269 consecutive patients with stage II-IIIA SCLC were retrospectively reviewed from January 2010 to December 2015. Of these, 116 patients received surgical resection, and 153 underwent non-surgical treatment. Resected patients were matched 1:1 with non-surgical patients ( $n=70$ in each group).

Results: The median follow-up was 30 months. The 1-, 3- and 5-year overall survival (OS) for matched patients were $80.0 \%, 44.3 \%$ and $31.7 \%$ in surgical group, and $80.0 \%, 24.3 \%$ and $20.0 \%$ in non-surgical group $(\mathrm{P}=0.009)$, respectively. Multivariate analysis in matched patients showed that surgery $(\mathrm{HR}=0.603,95 \% \mathrm{Cl}: 0.404-0.900)$ and $\mathrm{PCl}(\mathrm{HR}=0.637,95 \% \mathrm{Cl}: 0.427-0.950)$ were independent prognostic factors for OS. In subgroup analysis, OS benefit related to surgery was marginal for stage II $(\mathrm{P}=0.09)$ and IIIA patients $(\mathrm{P}=0.061)$, but was significant for selected stage IIIA patients who received adjuvant chemo-radiation and $\mathrm{PCl}(\mathrm{P}=0.01) . \mathrm{PCl}$ was associated with improved OS for non-surgical patients $(P=0.036)$, and stage IIIA of surgical patients $(P=0.047)$.
\end{abstract}

Conclusions: These findings suggest a potential OS benefit of surgery in stages II and IIIA patients, particularly in selected stage IIIA patients who received adjuvant chemo-radiation and PCI. The use of $\mathrm{PCl}$ for surgical patients with stage IIIA was associated with improved OS.

Key words: Small cell lung cancer; Surgical resection; Chemotherapy; Radiotherapy; Prophylactic cranial irradiation

\section{Introduction}

Small cell lung cancer (SCLC) represents approximately $13-15 \%$ of all lung cancers $[1,2]$, and is characterized by rapid growth, early metastases, and poor prognosis [3]. The standard treatment in most of the patients with limited disease SCLC is the combination of chemotherapy and thoracic radiotherapy (RT) [4, 5]. However, local recurrences are reported to be as high as $50 \%$, and the overall prognosis is poor [6-8]. Two randomized clinical trials
(RCT) performed two decades ago have proven that there is no survival advantage of surgery compared with non-surgical treatment $[9,10]$. However, recent data from some retrospective studies including several population database studies have demonstrated a potential benefit from surgery in patients with limited disease [11-19].

The positive role of prophylactic cranial irradiation (PCI) on long-term survival has been 
established for nonsurgical patients with limited disease and has been recommended by NCCN for patients who respond to treatment [20]. However, few studies have assessed the use of PCI for resected SCLC. Several retrospective studies have investigated the risk of brain metastasis according to the stage, but showed inconsistent results [21-25]. The value of PCI in this population needs further investigation.

Hence, this study aimed to assess the efficacy of surgery in stage II to III SCLC and evaluate the role of PCI in patients with resected SCLC.

\section{Patients and methods}

\section{Patients}

Between January 2010 and December 2015, 335 consecutive patients with limited stage SCLC were initially treated at our hospital. Most of the patients underwent standardized evaluation including thoracic and abdominal CT scanning or abdominal ultrasonography, brain magnetic resonance imaging (MRI) and bone radionuclide imaging, confirming the disease stage as stage II to III. TNM staging was determined according to the newly revised classification for lung cancer (American Joint Committee on Cancer seventh edition) [26]. Patients were excluded if they had stage IIIB disease $(n=46)$, without pathological identification $(n=5)$, who underwent incomplete resections $(\mathrm{n}=4)$, who lost to follow-up or with missing or erroneous data $(n=11)$. After excluding, a total of 269 patients were included in this study. Of these, 153 underwent non-surgical treatment, and 116 received surgical resection. This retrospective study was approved by the Regional Ethics Committee of our institution, in compliance with the Helsinki Declaration (1996).

\section{Treatment}

Of the 116 patients who underwent complete tumor resection followed by adjuvant chemotherapy or chemoradiotherapy, $98 \quad(84.5 \%)$ received lobectomy, $11(9.5 \%)$ received wedge resection and 7 $(6.0 \%)$ received pneumonectomy. Among them, 61 (52.6\%) received PCI. Of the 153 patients who underwent non-surgical treatment, all patients received chemotherapy combined with thoracic RT, and $99(64.7 \%)$ received PCI. The most frequently administered chemotherapy regimen was cisplatin and etoposide (PE) either in surgical group or non-surgical group, for every 3 weeks cycle, and used for a total of 4-6 cycles. Three-dimensional conformal RT (3D-CRT)/intensity modulated RT (IMRT) was used for patients receiving thoracic RT. The prescribed dose for thoracic RT was 50-60 Gy in 2.0-Gy daily fractions for patients in non-surgical group and 46-56 Gy in 2.0-Gy daily fractions for patients in surgical group. The prescribed dose for PCI was 30-40Gy in 2.0-3.0Gy daily fractions.

\section{Follow-up}

The last follow-up date was February 28, 2018. Most of the patients were followed up every 3-6 months for the first year, every 6 months for the next 2 years, and then annually until death. Survival information was collected via telephone if the patient could not visit the clinic on schedule.

\section{Statistical analysis}

Statistical analysis was performed using SPSS software version 24.0 (SPSS, Inc., Chicago, IL, USA). Overall survival (OS) was defined as the time from the initiation of treatment until death from any cause. Analysis of OS was carried out using the Kaplan-Meier method, and the difference between survival curves was tested by log-rank test. Variables with $\mathrm{P}<0.1$ were included for multivariate analysis using the Cox regression model. To reduce the effects of selection bias and confounding factors, propensity score matching (PSM) was performed to compare the groups. Patients were matched according to the propensity scores based on age, sex, TNM stage, and ECOG score with 1:1 ratio using the nearest neighbor matching method [27]. For all analyses, $\mathrm{P}<0.05$ was considered statistically significant.

\section{Results}

Characteristics of the study population before and after matching are shown in Table 1 . Characteristics of the study population before and after matching between surgical and NST groups are shown in Table 2. ECOG score, $\mathrm{N}$ stage, and TNM stage in the overall study cohort were significantly different between surgical and NST groups (Table 2). The PSM cohort (including 70 patients in surgical group and 70 patients in non-surgical group) showed an expected balance of covariates in the two groups (Table 2). The detailed treatment regimens for the two groups before and after matching are shown in Table 3. For surgical group, matched patients receiving adjust chemo-radiation was relatively more than non-matched patients $(71.4 \%$ vs. $50 \%)$. For NST group, the treatment was similar between matched and non-matched patients.

The response rates [complete response $(\mathrm{CR})+$ partial response (PR)] were $74.5 \%(114 / 153)$ in non-surgical group. Median follow-up for all patients was 30 months (range, 3-87 months), with 32 months (range, 3-79 months) for surgical group patients, and 28 months (range, 5-87 months) for the non-surgical group patients. 
Table 1. Characteristics of the study population before and after matching

\begin{tabular}{|c|c|c|}
\hline \multirow[t]{2}{*}{ Characteristic } & Before Matching $(n=269)$ & After Matching(n=140) \\
\hline & No (\%) & No (\%) \\
\hline \multicolumn{3}{|l|}{ Sex } \\
\hline Male & $173(64.3)$ & $81(57.9)$ \\
\hline Female & $96(35.7)$ & $59(42.1)$ \\
\hline \multicolumn{3}{|l|}{ Age } \\
\hline$\geq 60$ & $92(34.2)$ & $47(33.6)$ \\
\hline$<60$ & $177(65.8)$ & $93(66.4)$ \\
\hline \multicolumn{3}{|c|}{ Smoking history } \\
\hline Yes & $176(65.4)$ & $88(62.9)$ \\
\hline No & $93(34.6)$ & $52(37.1)$ \\
\hline \multicolumn{3}{|l|}{ ECOG score } \\
\hline $0-2$ & $259(96.3)$ & $140(100)$ \\
\hline 3 & $10(3.7)$ & $0(0)$ \\
\hline \multicolumn{3}{|l|}{ Tumor location } \\
\hline Central & $122(45.4)$ & $61(43.6)$ \\
\hline Peripheral & $147(54.6)$ & $79(56.4)$ \\
\hline \multicolumn{3}{|l|}{$\mathrm{T}$ stage } \\
\hline $\mathrm{T} 1$ & $51(19.0)$ & $24(17.1)$ \\
\hline $\mathrm{T} 2$ & $116(43.1)$ & $67(47.9)$ \\
\hline $\mathrm{T} 3$ & $97(36.1)$ & $49(35.0)$ \\
\hline $\mathrm{T} 4$ & $5(1.8)$ & $0(0)$ \\
\hline \multicolumn{3}{|l|}{$\mathrm{N}$ stage } \\
\hline No & $43(16.0)$ & 19(13.6) \\
\hline N1 & $86(32.0)$ & $39(27.9)$ \\
\hline N2 & $140(52.0)$ & $82(58.6)$ \\
\hline \multicolumn{3}{|l|}{ TNM Stage } \\
\hline II & $84(31.2)$ & $38(27.1)$ \\
\hline IIIA & $185(68.8)$ & $102(72.9)$ \\
\hline \multicolumn{3}{|l|}{ Treatment } \\
\hline Surgical & 116(43.1) & $70(50)$ \\
\hline NST & $153(56.9)$ & $70(50)$ \\
\hline
\end{tabular}

Abbreviations: NST: non-surgical treatment.

Table 2. Characteristics of the study population before and after matching between surgical and NST groups.

\begin{tabular}{|c|c|c|c|c|c|c|}
\hline \multirow[t]{2}{*}{ Characteristic } & \multicolumn{3}{|c|}{ Before Matching $(\mathrm{n}=269)$} & \multicolumn{3}{|c|}{ After Matching $(\mathrm{n}=140)$} \\
\hline & $\begin{array}{l}\begin{array}{l}\text { Surgical } \\
(\mathrm{n}=116)\end{array} \\
\mathrm{No}(\%)\end{array}$ & $\begin{array}{l}\text { NST } \\
(n=153) \\
\text { No(\%) }\end{array}$ & $\begin{array}{l}\mathrm{P} \\
\text { value }\end{array}$ & $\begin{array}{l}\text { Surgical } \\
(\mathrm{n}=70) \\
\mathrm{No}(\%)\end{array}$ & $\begin{array}{l}\text { NST } \\
(\mathrm{n}=70) \\
\mathrm{No}(\%)\end{array}$ & $\begin{array}{l}\mathrm{P} \\
\text { value }\end{array}$ \\
\hline \multicolumn{7}{|l|}{ Sex } \\
\hline Male & $77(66.4)$ & $96(62.7)$ & 0.538 & $38(54.3)$ & $43(61.4)$ & 0.392 \\
\hline Female & $39(33.6)$ & $57(37.3)$ & & $32(45.7)$ & $27(38.6)$ & \\
\hline \multicolumn{7}{|l|}{ Age } \\
\hline$\geq 60$ & $36(31.0)$ & $56(36.6)$ & 0.340 & $25(35.7)$ & $22(31.4)$ & 0.591 \\
\hline$<60$ & $80(69.0)$ & $97(63.4)$ & & $45(64.3)$ & $48(68.6)$ & \\
\hline \multicolumn{7}{|l|}{$\begin{array}{l}\text { Smoking } \\
\text { history }\end{array}$} \\
\hline Yes & $75(64.7)$ & $101(66.0)$ & 0.817 & $43(61.4)$ & $45(64.3)$ & 0.726 \\
\hline No & $41(35.3)$ & $52(34.0)$ & & $27(38.6)$ & $25(35.7)$ & \\
\hline \multicolumn{7}{|l|}{ ECOG score } \\
\hline $0-2$ & $116(100.0)$ & $143(93.5)$ & 0.013 & $70(100.0)$ & $70(100.0)$ & -- \\
\hline 3 & $0(0.0)$ & $10(6.5)$ & & $0(0.0)$ & $0(0.0)$ & \\
\hline \multicolumn{7}{|l|}{$\begin{array}{l}\text { Tumor } \\
\text { location }\end{array}$} \\
\hline Central & $48(41.4)$ & $74(48.4)$ & 0.254 & $32(45.7)$ & $29(41.4)$ & 0.609 \\
\hline Peripheral & $68(58.6)$ & $79(51.6)$ & & $38(54.3)$ & $41(58.6)$ & \\
\hline \multicolumn{7}{|l|}{ T stage } \\
\hline $\mathrm{T} 1$ & $22(19.0)$ & 29(19.0) & 0.227 & $9(12.9)$ & $15(21.4)$ & 0.148 \\
\hline $\mathrm{T} 2$ & $54(46.6)$ & $62(40.5)$ & & $39(55.7)$ & $28(40.0)$ & \\
\hline $\mathrm{T} 3$ & $40(34.4)$ & $57(37.3)$ & & $22(31.4)$ & $27(38.6)$ & \\
\hline $\mathrm{T} 4$ & $0(0)$ & $5(3.2)$ & & $0(0)$ & $0(0)$ & \\
\hline \multicolumn{7}{|l|}{$\mathrm{N}$ stage } \\
\hline N0 & $28(24.1)$ & $15(9.8)$ & $<0.001$ & $9(12.9)$ & $10(14.3)$ & 0.352 \\
\hline N1 & $43(37.1)$ & $43(28.1)$ & & $16(22.9)$ & $23(32.9)$ & \\
\hline N2 & $45(38.8)$ & $95(62.1)$ & & $45(64.3)$ & $37(52.9)$ & \\
\hline \multicolumn{7}{|l|}{ TNM stage } \\
\hline II & $65(56.0)$ & $19(12.4)$ & $<0.001$ & $19(27.1)$ & 19(27.1) & 1.00 \\
\hline IIIA & $51(44.0)$ & 134(87.6) & & $51(72.9)$ & $51(72.9)$ & \\
\hline
\end{tabular}

Abbreviations: NST: non-surgical treatment.
Table 3. The initial treatment before and after matching

\begin{tabular}{lll}
\hline Treatement & Before Matching, N(\%) & After Matching, N(\%) \\
\hline $\begin{array}{l}\text { Surgical group (n=116) } \\
\text { Surgical schedule }\end{array}$ & & \\
$\begin{array}{l}\text { Surgery only } \\
\text { Surgery + CT }\end{array}$ & $11(9.5)$ & $5(7.1)$ \\
$\begin{array}{l}\text { Surgery + CRT } \\
\text { Surgical procedure }\end{array}$ & $58(50.5)$ & $15(21.4)$ \\
lobectomy & $98(84.5)$ & $50(71.4)$ \\
wedge resection & $11(9.5)$ & $60(85.7)$ \\
pneumonectomy & $7(6.0)$ & $6(8.6)$ \\
PCI & & $4(5.7)$ \\
Yes & $61(52.6)$ & \\
No & $55(47.4)$ & $44(62.9)$ \\
NST group (n=153) & & $26(37.1)$ \\
NST schedule & & \\
CT only & $0(0)$ & $0(0)$ \\
RT only & $0(0)$ & $0(0)$ \\
CRT & $153(100)$ & $70(100)$ \\
PCI & & \\
Yes & $99(64.7)$ & $44(62.9)$ \\
No & $54(35.3)$ & $26(37.1)$ \\
\hline Abbreviations: NST: non-surgical treatment; CT: chemotherapy; RT: radiotherapy; \\
CRT: chemoradiotherapy; PCI: prophylactic cranial irradiation.
\end{tabular}

\section{Survival}

The median survival for all patients was 30 months, with 38 months for the surgical group, and 28 months for the non-surgical group patients. The 1-, 3and 5 -year OS rates were $82.8 \%, 50.7 \%$ and $38.8 \%$ for surgical group, and $83.0 \%, 37.7 \%$ and $24.9 \%$ for non-surgical group $(\mathrm{P}=0.029)$, respectively, which showed statistical significance. These findings were confirmed in the matched patients. The median survival for all patients was 23 months, with 32 months for the surgical group, and 20 months for the non-surgical group. The 1-, 3- and 5-year OS were $80.0 \%, 44.3 .0 \%$ and $31.7 \%$ for surgical group, and $80.0 \%, 24.3 \%$ and $20.0 \%$ for non-surgical group $(\mathrm{P}=0.009$; Fig. 1A), respectively, which showed statistical significance.

\section{Analysis of factors related to OS}

Univariate analysis of all and matched patients demonstrated that surgery $(\mathrm{P}=0.029$ and $\mathrm{P}=0.009)$ and PCI $\quad(\mathrm{P}=0.03$ and $\mathrm{P}=0.037)$ were significantly associated with improved OS (Tables 4, 5). Lower TNM stage was significantly considered to be a positive prognostic factor for all patients $(\mathrm{P}=0.024$; Table 4).

In multivariate Cox regression analysis, PCI was an independent prognostic factor for OS of all [hazards ratio $(\mathrm{HR})=0.665,95 \%$ confidence interval (CI): 0.492-0.899; (Table 4) and matched patients (HR=0.637, 95\%CI: 0.427-0.950; Table 5). Additionally, surgery was an independent prognostic factor in matched patients $(\mathrm{HR}=0.603$, 95\% CI: 0.404-0.900; Table 5). 

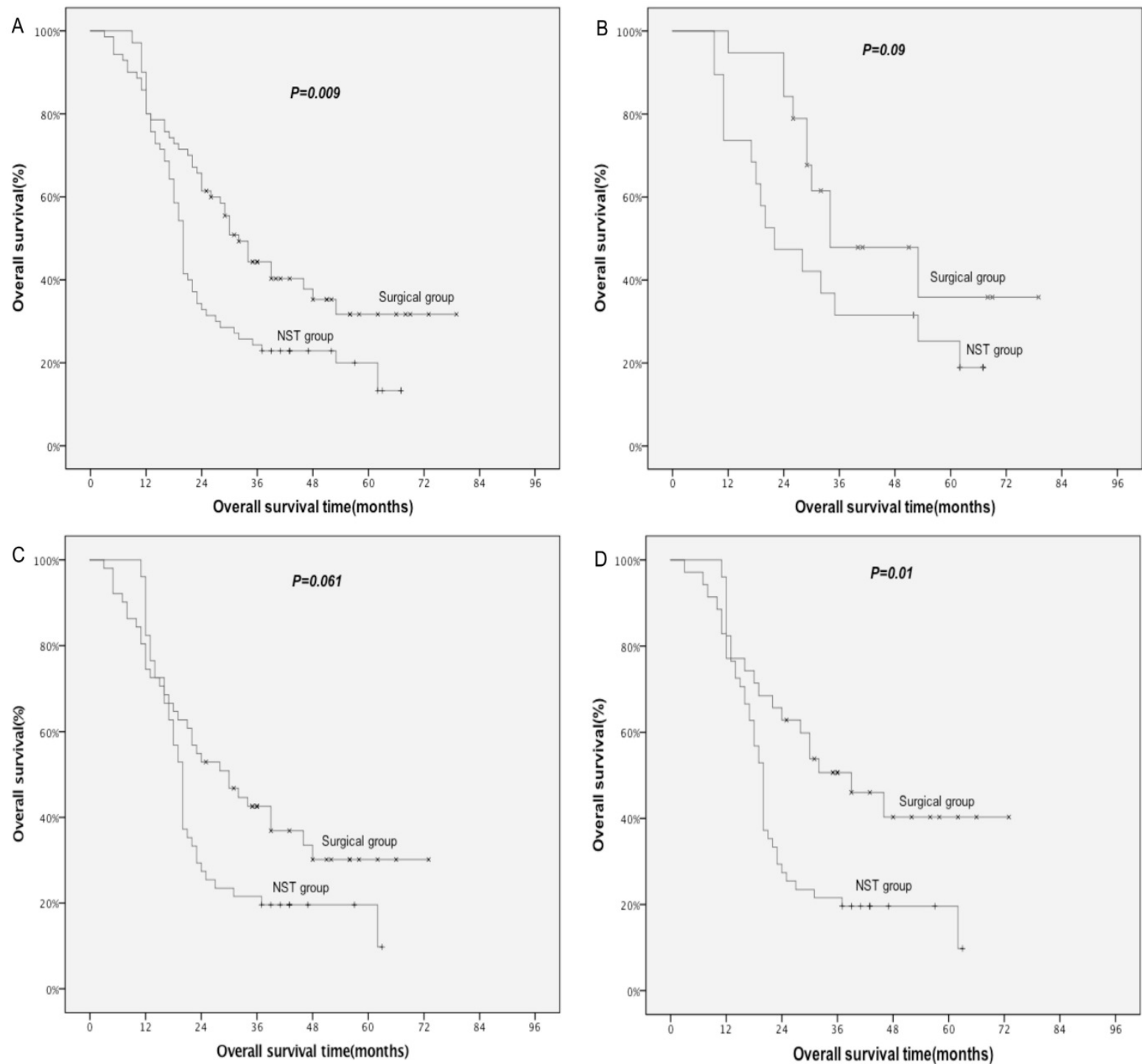

Figure 1. Comparison of OS between NST group and surgical group in matched patients. A: all; B: stage II; C: stage IIIA; D: selected stage IIIA. NST: non-surgical treatment; selected stage IIIA: surgical patients who received adjuvant chemo-radiation and prophylactic cranial irradiation.

Subgroup analysis of matched patients (Table 6) demonstrated a marginal OS benefit from surgery for stage II ( $\mathrm{P}=0.09$; Fig. 1B) and IIIA ( $\mathrm{P}=0.061$; Fig. $1 \mathrm{C})$. A significantly improved OS was observed for selected stage IIIA patients who received adjuvant chemoradiotherapy and PCI in surgical group when compared with stage IIIA patients in non-surgical group ( $\mathrm{P}=0.01$; Fig. 1D).

Improved OS related to PCI was found for non-surgical patients $(\mathrm{P}=0.036)$, but not for surgical patients ( $\mathrm{P}=0.172$; Table 7; Fig. 2A). Further subgroup analysis of surgical patients demonstrated a survival advantage with the use of PCI in stage IIIA patients $(\mathrm{P}=0.047$; Table 7; Fig. 2B).

\section{Discussion}

The role of surgery for limited-stage SCLC remains controversial due to lack of conclusive evidence. A recent review by Barnes et al. examined three RCTs $[9,10,28]$ that evaluated surgery versus nonoperative management for SCLC [29]. The study concluded that the current evidence does not support a role for surgical resection in the management of limited-stage SCLC. However, these RCTs were conducted more than two decades ago were of very low quality and had some limitations. For example, for the Fox' trial [9], chemotherapy was not included as part of the standard treatment protocol, and only $34 / 71$ participants underwent surgical resection in the surgical arm. Since the time these trials were conducted, there have been many developments in SCLC therapy such as modern RT technique, and better diagnostic and surgical tools. Recently, data from a series of observational studies have supported a role for surgery in the management of limited-stage SCLC [11-19]. In the present study, the 1-, 3- and 
5-year OS rates in surgical group were significantly benefits from surgery were maintained in the higher than in non-surgical group. The survival propensity matched patients.

Table 4. Univariate and multivariate analysis of factors related to OS (before matching, $n=269$ )

\begin{tabular}{|c|c|c|c|c|c|c|c|}
\hline \multirow{2}{*}{ Variable } & \multirow{2}{*}{ No. } & \multirow{2}{*}{$1-\operatorname{Yr}(\%)$} & \multirow{2}{*}{$3-\operatorname{Yr}(\%)$} & \multirow{2}{*}{$5-\operatorname{Yr}(\%)$} & \multirow{2}{*}{$\begin{array}{l}\text { Univariate } \\
\mathrm{P} \text { value }\end{array}$} & \multicolumn{2}{|l|}{ Multivariate } \\
\hline & & & & & & HR $(95 \% \mathrm{CI})$ & $P$ value \\
\hline \multicolumn{8}{|l|}{ Sex } \\
\hline Male & 173 & 79.8 & 40.1 & 28.3 & \multirow[t]{2}{*}{0.169} & & \\
\hline Female & 96 & 88.5 & 49.1 & 34.7 & & & \\
\hline \multicolumn{8}{|l|}{ Age } \\
\hline$\geq 60$ & 92 & 79.3 & 39.9 & 25.1 & \multirow[t]{2}{*}{0.180} & & \\
\hline$<60$ & 177 & 84.7 & 45.1 & 33.6 & & & \\
\hline \multicolumn{8}{|c|}{ Smoking history } \\
\hline Yes & 176 & 80.1 & 41.3 & 31.5 & \multirow[t]{2}{*}{0.652} & & \\
\hline No & 93 & 88.2 & 47.0 & 29.5 & & & \\
\hline \multicolumn{8}{|c|}{ Tumor location } \\
\hline Central & 122 & 83.6 & 42.4 & 30.6 & \multirow[t]{2}{*}{0.962} & & \\
\hline Peripheral & 147 & 82.3 & 44.2 & 30.9 & & & \\
\hline \multicolumn{8}{|l|}{ T Stage } \\
\hline $\mathrm{T} 1$ & 51 & 90.2 & 41.8 & 35.5 & \multirow[t]{4}{*}{0.161} & & \\
\hline T2 & 116 & 83.6 & 48.8 & 34.8 & & & \\
\hline $\mathrm{T} 3$ & 97 & 80.4 & 37.9 & 23.7 & & & \\
\hline $\mathrm{T} 4$ & 5 & 40.0 & 40.0 & 40.0 & & & \\
\hline \multicolumn{8}{|l|}{ N Stage } \\
\hline No & 43 & 79.1 & 46.2 & 34.4 & \multirow{3}{*}{\multicolumn{2}{|c|}{0.470}} & \\
\hline N1 & 86 & 88.4 & 43.8 & 35.6 & & & \\
\hline N2 & 140 & 80.7 & 41.9 & 26.4 & & & \\
\hline \multicolumn{8}{|l|}{ TNM Stage } \\
\hline II & 84 & 85.7 & 51.2 & 41.0 & \multirow{2}{*}{0.024} & \multirow{2}{*}{$0.713(0.478-1.062)$} & \multirow[t]{2}{*}{0.096} \\
\hline IIIA & 185 & 81.6 & 39.7 & 25.7 & & & \\
\hline \multicolumn{8}{|l|}{ Surgery } \\
\hline Yes & 116 & 82.8 & 50.7 & 38.8 & \multirow[t]{2}{*}{0.029} & \multirow[t]{2}{*}{$0.808(0.563-1.158)$} & \multirow[t]{2}{*}{0.246} \\
\hline No & 153 & 83.0 & 37.7 & 24.9 & & & \\
\hline \multicolumn{8}{|l|}{ PCI } \\
\hline Yes & 160 & 83.8 & 48.8 & 35.5 & \multirow{2}{*}{0.030} & $0.665(0.492-0.899)$ & 0.008 \\
\hline No & 109 & 81.7 & 35.2 & 23.0 & & & \\
\hline
\end{tabular}

Table 5. Univariate and multivariate analysis of factors related to OS (after matching, $n=140$ )

\begin{tabular}{|c|c|c|c|c|c|c|c|}
\hline \multirow[t]{2}{*}{ Variable } & \multirow[t]{2}{*}{ No. } & \multirow[t]{2}{*}{$1-\mathrm{Yr}(\%)$} & \multirow[t]{2}{*}{$3-\operatorname{Yr}(\%)$} & \multirow[t]{2}{*}{$5-\operatorname{Yr}(\%)$} & \multirow{2}{*}{$\begin{array}{l}\text { Univariate } \\
\mathrm{P} \text { value }\end{array}$} & \multicolumn{2}{|l|}{ Multivariate } \\
\hline & & & & & & HR $(95 \% \mathrm{CI})$ & P value \\
\hline \multicolumn{8}{|l|}{ Sex } \\
\hline Male & 81 & 76.5 & 30.7 & 21.7 & 0.325 & & \\
\hline Female & 59 & 84.7 & 39.8 & 31.6 & & & \\
\hline \multicolumn{8}{|l|}{ Age } \\
\hline$\geq 60$ & 47 & 74.5 & 30.9 & 17.2 & 0.414 & & \\
\hline$<60$ & 93 & 82.8 & 36.0 & 30.8 & & & \\
\hline \multicolumn{8}{|c|}{ Smoking history } \\
\hline Yes & 88 & 78.4 & 34.1 & 27.0 & 0.894 & & \\
\hline No & 52 & 82.7 & 34.6 & 24.7 & & & \\
\hline \multicolumn{8}{|c|}{ Tumor location } \\
\hline Central & 61 & 78.7 & 37.5 & 28.7 & 0.612 & & \\
\hline Peripheral & 79 & 81.0 & 31.8 & 23.7 & & & \\
\hline \multicolumn{8}{|l|}{ T Stage } \\
\hline $\mathrm{T} 1$ & 24 & 87.5 & 26.5 & 26.5 & 0.176 & & \\
\hline $\mathrm{T} 2$ & 67 & 80.6 & 42.9 & 31.6 & & & \\
\hline $\mathrm{T} 3$ & 49 & 75.5 & 26.0 & 17.1 & & & \\
\hline \multicolumn{8}{|l|}{ N Stage } \\
\hline No & 19 & 84.2 & 35.1 & 26.3 & 0.789 & & \\
\hline N1 & 39 & 84.6 & 32.6 & 23.2 & & & \\
\hline N2 & 82 & 76.8 & 35.0 & 27.6 & & & \\
\hline \multicolumn{8}{|l|}{ TNM Stage } \\
\hline II & 38 & 84.2 & 39.9 & 31.1 & 0.081 & $0.648(0.409-1.026)$ & 0.064 \\
\hline IIIA & 102 & 78.4 & 32.1 & 24.4 & & & \\
\hline \multicolumn{8}{|l|}{ Surgery } \\
\hline Yes & 70 & 80.0 & 44.3 & 31.7 & 0.009 & $0.603(0.404-0.900)$ & 0.013 \\
\hline No & 70 & 80.0 & 24.3 & 20.0 & & & \\
\hline \multicolumn{8}{|l|}{$\mathrm{PCI}$} \\
\hline Yes & 88 & 84.1 & 40.2 & 32.6 & 0.037 & $0.637(0.427-0.950)$ & 0.027 \\
\hline No & 52 & 73.1 & 25.0 & 14.4 & & & \\
\hline
\end{tabular}

Abbreviations: PCI: prophylactic cranial irradiation. 

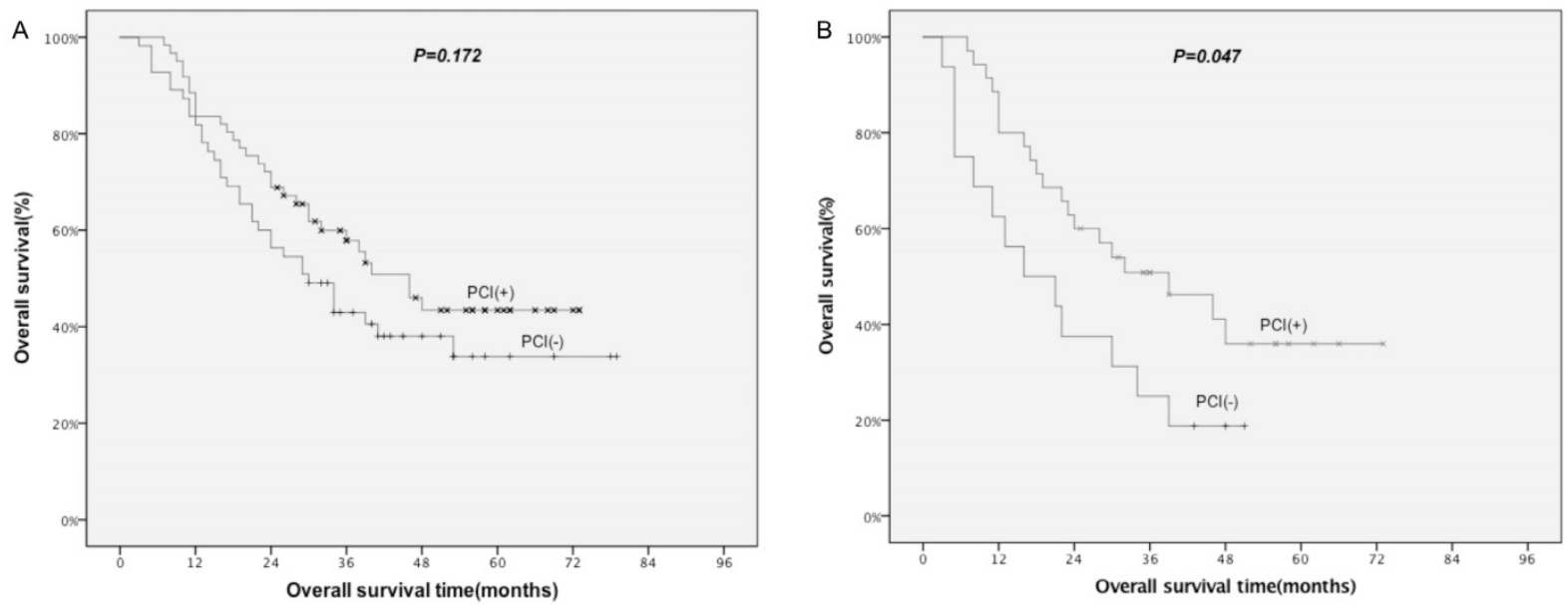

Figure 2. Comparison of OS by PCl for surgical patients. A: all patients; B: patients with stage IIIA. PCl: prophylactic cranial irradiation.

Table 6. Comparison of survival between surgical and NST group by stage (after matching)

\begin{tabular}{llllll}
\hline & $\mathrm{N}$ & $1-\mathrm{Yr}(\%)$ & $3-\mathrm{Yr}(\%)$ & $5-\mathrm{Yr}(\%)$ & P value \\
\hline Stage II & 38 & & & & \\
Surgical & 19 & 94.7 & 47.8 & 35.9 & 0.09 \\
NST & 19 & 73.7 & 31.6 & 25.3 & \\
Stage IIIA & 102 & & & & \\
Surgical & 51 & 74.5 & 42.6 & 30.2 & $0.061^{*}$ \\
Surgical-selecteda & 35 & 77.1 & 50.7 & 40.3 & $0.010^{*}$ \\
NST & 51 & 82.4 & 21.6 & 19.6 & \\
\hline
\end{tabular}

Abbreviations: NST: non-surgical treatment; a: stage IIIA patients who received adjuvant chemoradiotherapy and prophylactic cranial irradiation in surgical group; *: compared with NST.

Table 7. Comparison of survival by $\mathrm{PCl}$

\begin{tabular}{llllll}
\hline & $\mathrm{N}$ & 1-Yr (\%) & $3-\mathrm{Yr}(\%)$ & $5-\mathrm{Yr}(\%)$ & P value \\
\hline NST & 153 & & & & \\
PCI(+) & 99 & 83.8 & 43.4 & 30.7 & 0.036 \\
PCI(-) & 54 & 81.5 & 27.0 & 13.2 & \\
Surgical & 116 & & & & \\
PCI(+) & 61 & 83.6 & 57.9 & 43.4 & 0.172 \\
PCI(-) & 55 & 81.8 & 43.0 & 33.8 & \\
Surgical-stage IIIA & 51 & & & & \\
PCI(+) & 35 & 80.0 & 50.8 & 35.9 & 0.047 \\
PCI(-) & 16 & 62.5 & 25.0 & 18.8 & \\
\hline
\end{tabular}

Abbreviations: NST: non-surgical treatment; PCI: prophylactic cranial irradiation.

As SCLC responds well to chemotherapy and radiotherapy, surgery is considered to be a standard treatment option mainly for early stage SCLC. Current NCCN guidelines have recommended surgical resection for clinical stage I (T1-2, N0) disease [20]. However, no consensus was drawn for the role of surgery in stage II and stage III diseases. Gaspar, et al. [30] analyzed the National Cancer Database (NCDB) and found that surgery was significantly associated with improved survival in patients with stage II and stage III SCLC. Conversely, another NCDB based Propensity-Matched Analysis for limited-stage SCLC [11] showed that surgery was related to longer survival time for stage I patients, but survival differences were attenuated for stage II and IIIA. However, in their study, only $35.5 \%$ received lobectomy, and less than $50 \%$ of stage IIIA surgical patients were adjusted for chemo-radiation. A retrospective analysis of the Surveillance, Epidemiology, and End Results (SEER) between 1988 and 2002 identified 863 patients with SCLC who underwent surgery [13]. Results revealed that lobectomy was associated with the best outcomes, and there was a significant survival benefit from the addition of PORT in patients with N2 disease. In our study, most of the matched surgical patients with stage IIIA were adjusted for chemo-radiation, and all surgical patients underwent complete tumor resection, and $85.7 \%$ of them received lobectomy. All these findings might help to improve OS for surgical patients. We found a marginal OS benefit from surgery for stages II and IIIA patients. In further subgroup analysis of stage IIIA, a significantly improved OS from surgery was observed in patients who received adjuvant chemo-radiation and PCI $(\mathrm{P}=0.01)$. These results suggested a potential OS benefit of surgery in stages II and IIIA, particularly in selected stage IIIA patients.

The positive role of PCI has been recognized for patients with limited SCLC who respond to treatment. However, few studies have investigated the value of PCI for resected disease. Several scholars have retrospectively assessed the risk of brain relapse after surgery for limited SCLC, suggesting that PCI might have a role in surgically resected stages (p-stage) II and III patients because of their relatively high frequency of brain metastasis, but not for stage (p-stage) I disease due to lower incidence of brain metastases [22-25,31-32]. In the present study, PCI was considered to be an independent prognostic factor for OS. Improved OS related to PCI was found for non-surgical patients, but not for surgical patients. However, further subgroup analysis showed a survival advantage with the use of PCI in patients with stage IIIA $(\mathrm{P}=0.047)$. 
Our study has several limitations. Firstly, this is a retrospective analysis. However, we performed PSM, which eliminated potential bias by creating two comparable groups. Secondly, modern tools such as positron emission tomography-computed tomography (PET-CT) or mediastinoscopy were not routinely used. Therefore, the diagnosis of clinical stage was less accurate.

\section{Conclusions}

In summary, these results suggest a potential OS benefit of surgery in stages II and IIIA patients, particularly in selected stage IIIA patients who received adjuvant chemoradiotherapy and PCI. The use of PCI for surgical patients with stage IIIA was associated with improved OS. Further prospective RCTs are needed to confirm these findings.

\section{Competing Interests}

The authors have declared that no competing interest exists.

\section{References}

[1] Govindan R, Page N, Morgensztern D, et al. Changing epidemiology of small-cell lung cancer in the United States over the last 30 years: analysis of the surveillance, epidemiologic, and end results database. J Clin Oncol. 2006; 24: 4539-44.

[2] Gaspar LE, McNamara EJ, Gay EG, et al. Small-cell lung cancer: prognostic factors and changing treatment over 15 years. Clin Lung Cancer. 2012; 13: 115-22.

[3] Goldberg SB, Willers H, Heist RS. Multidisciplinary management of small cell lung cancer. Surg Oncol Clin N Am. 2013; 22: 329-43.

[4] Turrisi AT 3rd. Limited stage small cell lung cancer: treatment and therapy. Curr Treat Options Oncol. 2003; 4: 61-64

[5] Aupérin A, Arriagada R, Pignon JP, et al. Prophylactic cranial irradiation for patients with small-cell lung cancer in complete remission. Prophylactic Cranial Irradiation Overview Collaborative Group. N Engl J Med. 1999; 341: 476-84.

[6] Pignon JP, Arriagada R, Ihde DC, et al. A meta-analysis of thoracic radiotherapy for small-cell lung cancer. N Engl J Med. 1992; 327: 1618-24.

[7] Turrisi AT 3rd, Kim K, Blum R, Sause WT, et al. Twice-daily compared with once-daily thoracic radiotherapy in limited small-cell lung cancer treated concurrently with cisplatin and etoposide. N Engl J Med. 1999; 340: 265-71.

[8] van Meerbeeck JP, Fennell DA, De Ruysscher DK. Small-cell lung cancer. Lancet. 2011; 378: 1741- 55.

[9] Fox W, Scadding JG. Medical Research Council comparative trial of surgery and radiotherapy for primary treatment of small-celled or oat-celled carcinoma of bronchus. Ten-year follow-up. Lancet. 1973; 2: 63-65.

[10] Lad T, Piantadosi S, Thomas P, Payne D, Ruckdeschel J, Giaccone G. A prospective randomized trial to determine the benefit of surgical resection of residual disease following response of small cell lung cancer to combination chemotherapy. Chest. 1994; 106 (Suppl 6): S320- S323.

[11] Wakeam E, Acuna SA, Leighl NB, et al. Surgery Versus Chemotherapy and Radiotherapy For Early and Locally Advanced Small Cell Lung Cancer: A Propensity-Matched Analysis of Survival. Lung Cancer. 2017; 109: 78-88.

[12] Ahmed Z, Kujtan L, Kennedy KF, Davis JR, Subramanian J. Disparities in the Management of Patients With Stage I Small Cell Lung Carcinoma (SCLC): A Surveillance, Epidemiology and End Results (SEER) Analysis. Clin Lung Cancer. 2017; 18: e315-e325.

[13] Schreiber D, Rineer J, Weedon J, et al. Survival outcomes with the use of surgery in limited-stage small cell lung cancer: should its role be re-evaluated? Cancer. 2010; 116: 1350-57.

[14] Combs SE, Hancock JG, Boffa DJ, Decker RH, Detterbeck FC, Kim AW. Bolstering the case for lobectomy in stages I, II, and IIIA small-cell lung cancer using the National Cancer Data Base. J Thorac Oncol. 2015; 10: 316-23.

[15] Zhu H, Zhou Z, Xue Q, Zhang X, He J, Wang L. Treatment modality selection and prognosis of early stage small cell lung cancer: retrospective analysis from a single cancer institute. Eur J Cancer Care (Engl). 2013; 22:789-96.

[16] Badzio A, Kurowski K, Karnicka-Mlodkowska H, Jassem J. A retrospective comparative study of surgery followed by chemotherapy vs. non-surgical management in limited-disease small cell lung cancer. Eur J Cardiothorac Surg. 2004; 26: 183-88.
[17] Zhang J, Li S, Chen X, Han J, Nie J, Dai L, et al. Retrospective study of surgery versus non-surgical management in limited-disease small cell lung cancer. Thorac Cancer. 2014; 5: 405-10.

[18] Hou SZ, Cheng ZM, Wu YB, et al. Evaluation of short-term and long-term efficacy of surgical and non-surgical treatment in patients with early-stage small cell lung cancer: A comparative study. Cancer Biomark. 2017; 19: 249-56.

[19] Takenaka T, Takenoyama M, Inamasu E, et al. Role of surgical resection for patients with limited disease-small cell lung cancer. Lung Cancer. 2015; 88: 52-6.

[20] [Internet] National Comprehensive Cancer Network Clinical Practice Guidelines in Oncology for Small Cell Lung Cancer (Version 2. 2018-January 17th, 2018). Available from: https://www.nccn.org/professionals/ physician_gls.

[21] Eberhardt W, Stamatis G, Stuschke M, et al. Prognostically orientated multimodality treatment including surgery for selected patients of small-cell lung cancer patients stages IB to IIIB: long-term results of a phase II trial. Br J Cancer. 1999; 81: 1206-12

[22] Gong L, Wang QI, Zhao L, Yuan Z, Li R, Wang P. Factors affecting the risk of brain metastasis in small cell lung cancer with surgery: is prophylactic cranial irradiation necessary for stage I-III disease? Int J Radiat Oncol Biol Phys. 2013; 85: 196-200.

[23] Zhu H, Bi Y, Han A, et al. Risk factors for brain metastases in completely resected small cell lung cancer: a retrospective study to identify patients most likely to benefi $t$ from prophylactic cranial irradiation. Radiat Oncol. 2014; 9: 216.

[24] Nakamura H, Kato Y, Kato H. Outcome of surgery for small-cell lung cancer -response to induction chemotherapy predicts survival. Thorac Cardiovasc Surg. 2004; 52: 206-10

[25] Ogawa S, Horio Y, Yatabe Y, et al. Patterns of recur-rence and outcome in patients with surgically resected small cell lung cancer. Int J Clin Oncol. 2012; 17: 218-24.

[26] Goldstraw P, Crowley J, Chansky K, et al. International Association for the Study of Lung Cancer International StagingCommittee; Participating Institutions. The IASLC Lung Cancer Staging Project:proposals for the revision of the TNM stage groupings in the forthcoming (seventh) edition of the TNM Classification of malignant tumours. J Thorac Oncol. 2007; 2: 706-14.

[27] PSMATCH2: Stata module to perform full Mahalanobis and propensity score matching, common support graphing, and covariate imbalance testing [computer program]. Version 4.0.11. Chestnut Hill, MA: Boston College; 2003.

[28] Liao M, Zhao J, Zhou Y. Multimodality therapy of late stage lung cancer. Zhonghua Zhong Liu Za Zhi. 1995; 17: 384-86. [In Chinese]

[29] Barnes H, See K, Barnett S, Manser R. Surgery for limited-stage small cell lung cancer. Cochrane Database Syst Rev. 2017; 4: CD011917.

[30] Gaspar LE, McNamara EJ, Gay EG, et al. Small-cell lung cancer: prognostic factors and changing treatment over 15 years. Clin Lung Cancer. 2012; 13: $115-22$.

[31] Xu J, Yang H, Fu X, et al. Prophylactic Cranial Irradiation for Patients with Surgically Resected Small Cell Lung Cancer. J Thorac Oncol. 2017; 12: 347-53.

[32] Zhu H, Guo H, Shi F, et al. Prophylactic cranial irradiation improved the overall survival of patients with surgically resected small cell lung cancer, but not for stage I disease. Lung Cancer. 2014; 86: 334-38. 